\title{
Zero-Hours and Other Very Atypical Forms of Employment Contracts in European and International Regulation
}

\author{
Vincenzo Ferrante \\ Catholic University of Milan, Milan, Italy
}

\begin{abstract}
In the effort to develop a comprehensive approach to better and good jobs, it is a topic of hot debate as to whether the introduction (temporarily or on a permanent basis) of statutory legislation-different from the general law applying to subordinate workers-may encourage employers and employees to operate within the formal economy and in the context of regular contracts of employment. The essay analyzes from a comparative point of view not the traditional forms of non-standard employment, but those special working arrangements, that may involve very short hours ("marginal" part time: generally, fewer than 15 hours per week) or no predictable fixed hours, and those according to which the employer has no obligation to provide a set number of hours of work. The conclusion is that extremely atypical forms of work appear to give an answer to the challenges of the market labor of the urban economies of the 21 st century, but that special legal provisions are needed to guarantee individual right to fair wages and to protect personal life of employees.

Keywords: shadow economy, undeclared work, informal employment, work on a casual basis, part-time workers job on-call, equal treatment, mini-jobs
\end{abstract}

\section{Zero-Hours and Very Atypical Forms of Employment Contracts Worldwide Diffusion}

Since the latest years of the 20th century, the labour market has experimented across the countries very atypical forms of employment and other special working arrangements that may involve very short hours ("marginal" part time: generally, fewer than 15 hours per week) or no predictable fixed hours. These latter arrangements, known as "on-call work" ", according to which the employer has no obligation to provide a set number of hours of work, come under different contractual forms depending on the country and include so-called "zero-hours contracts. Of course, the hours actually worked can in fact be equal to those of full-time workers, or even be higher.

Other cases, largely widespread in the internal labour market of many countries, can be labelled as voucher-based work, when the employer acquires a voucher from a third party to be used as a payment for a service from a worker, rather than cash.

In this sense, particular attention has been paid not only to German mini-jobs allowing a monthly individual net income up to $€ 450$, and considered as a form of part-time (now without a working time limit on weekly basis), but also to the French CESU (cheque employ service universel), a voucher system which seems to have targeted the result to an important shift from undeclared to legal work.

Vincenzo Ferrante, full professor of Labour Law, Catholic University of Milan, Milan, Italy. 
The idea is that the creation of a legal environment favourable to the declaration of certain economic activities, by simplifying administrative procedures and reducing the labour costs and legal constraints, may facilitate the emergence of undeclared work as a part of the formal economy ${ }^{1}$.

On the other hand, these marginal workers are more exposed to the risk of being trapped in insecure contracts without a tangible prospect of transition to more permanent jobs, and need support to have access to training, which can give them the chance to climb the social and pay ladder ${ }^{2}$. Also, for people who wish (or are available) to work only on a causal or intermittent basis (like workers with family responsibilities, students, semiretired persons), it is important to introduce limits regarding on-demand worklessness because generally there is an evident de facto imbalance in bargaining power that prevents them from negotiating their working schedules, and consequently from having autonomous control over their own private life ${ }^{3}$.

In any cases, it seems evident that the so-called gig-economy requires a simplified regulation of the employer-employee relationship, to make the acceptance of a job offer on a purely contingent basis easier and the duties which lay a burden on each party clearer. In this light, it seems important to investigate the already established instruments for part time and fixed term workers, to understand if, and to what extent, protection could be founded on the principle of equal treatment and the other prescriptions laid down for this forms of employment.

The present paper, looking into the legislation of four European States (F, G, NL, and I) and, just in outline, two other jurisdictions (AUS and China), aims to:

- provide an updated list of these special forms of work ${ }^{4}$;

- verify how much of the European regulation and of the ILO provisions can apply to them;

- verify, even in the absence of quantitative measurements, if these special regulations are useful in counteracting undeclared work or whether, on the contrary, they do not result in facilitating a reduction of undeclared work;

- check whether such special rules could play a role in combating unemployment, by preventing the complete expulsion of workers from the labor market;

- verify whether, in view of the aforementioned purposes, such simplified rules can be allowed (and how long for) to deviate from the principles otherwise valid for all other forms of work.

\section{European Case Law and Legislation on Marginal Workers}

It is not clear if the entire EU social acquis can be applied to these special forms of contract. The extremely marginal nature of the activity and the discontinuity and variation in income levels pose problems in terms of trade union rights, compliance with working time limits, and guarantees of rests and breaks for annual and sickness leave, as well as the application of the principle of equal treatment, in particular as regulated by the European directives for fixed-term contracts and part-time work. In the same sense, waiting for a general

\footnotetext{
1 See Megner and Nolte cases quoted below parr. 28 and 32.

2 See "Commission Staff Working Document Impact Assessment Accompanying the Document Proposal for a Directive of the European Parliament and of the Council on Transparent and Predictable Working Conditions in the European Union", 21.12.2017, SWD (2017) 478 final, 40.

3 Ibid., 18.

4 A good starting point for EU countries can be found in Annex 4 to "Impact Assessment for the Proposed Directive on Transparent and Predictable Working Conditions in the EU”, 21.12.2017, SWDD (2017) 478 final (p. 114 ff.).
} 
framework instrument on work-life balance ${ }^{5}$, there is no provision with regard to predictability of work schedules.

The European Court of Justice's case law has recognized that German "minor" workers can enjoy the right to free movement ${ }^{6}$ but it must be admitted that it is controversial if the worker is ever entitled to equal treatment from all points of view and, therefore, with special reference to social security aspects, too.

In an older case ${ }^{7}$, the Court held that exclusion by a collective agreement from entitlement to a special annual bonus provided for by that collective agreement of persons in employment, which involves a normal working week of less than 15 hours, constitutes indirect discrimination based on sex, where that exclusion applies independently of the sex of the worker but actually affects a considerably higher percentage of women than men. Called upon consequently to enforce application of the same principle to on call employment, in application of the part time directive 97/81, the Court in a well-known case refused to recognize the infringement of the general principle of equal treatment, noting that "no full-time worker in the same establishment has the same type of contract or employment relationship" as the plaintiff".

In other cases, the Court has held that Council Directive 79/7/EEC on the progressive implementation of the principle of equal treatment for men and women in matters of social security must be interpreted as not precluding national provisions under which "minor" employment is excluded from various statutory insurance schemes, even where they affect considerably more women than men, since the national legislature was reasonably entitled to consider that the legislation in question was necessary in order to achieve a social policy aim unrelated to any discrimination on grounds of sex?

No judgement has dealt, nevertheless, with the problems of work-life balance or the risks to health and safety resulting from multiple jobs.

The selective approach of European directives should not surprise us: The European discipline is mainly aimed at regulating the conditions of freedom of movement and, from this perspective, it can certainly leave marginal situations to the discretion of Member States, at least at the beginning. From its side, jurisprudence has been able to broaden the concept of the worker, with a view to ensuring freedom of movement for the citizens of the Union, without calling into question the more selective choice of directives regulating working conditions. Things change when, after the enormous development of these forms of atypical work, Europe wants to equip itself with instruments of general application, even in the absence of specific legislative competences on this point.

Not surprisingly, the European Parliament has invited social partners and the Commission itself to present a proposal for a framework directive on decent working conditions in all forms of employment ${ }^{10}$, extending existing minimum EU standards to new kinds of employment relationships, in order to ensure for every worker a core set of enforceable rights, regardless of the type of contract or employment relationship.

\footnotetext{
${ }^{5}$ See "Proposal for a Directive of the European Parliament and of the Council on Work-Life Balance for Parents and Carers and Repealing Council Directive 2010/18/EU”, 26.4.2017, COM/2017/0253 final.

6 CJEU Judgment of 4 February 2010, Hava Genc v Land Berlin, Case C-14/09, EU:C:2010:57.

7 See Krüger (ECLI:EU:C:1999:396) and Wippel (ECLI:EU:C:2004:607) cases.

8 Judgment of the Court (Grand Chamber) 12 October 2004, C-313/02, Wippel, EU:C:2004:607.

9 Judgment of the Court 14 December 1995, C-317/93, Nolte v Landesversicherungsanstalt Hannover, EU:C:1995:438; see in the same sense Judgement 14 December 1995, C-444/93, Megner v. Innungskranken-kasse Vorderpfalz; EU:C:1995:442.

${ }^{10}$ See EP Resolution of 19 January 2017 on "A European Pillar of Social Rights"; see also EP Resolution of 4 July 2017 on "Working Conditions and Precarious Work".
} 
This broader approach (enlarged to equal treatment, health and safety protection, maternity leave, provisions on working time and rests, work-life balance, access to training, in-work support for people with disabilities, adequate information, consultation and participation rights, freedom of association and representation, collective bargaining, and collective action) to be successful has to face the fact that, according to international instruments, exceptions authorize Member States to restrict the application of general rules, excluding marginal workers from the scope of legislation.

It is well known that Clause No. 2 of Council Directive 97/81/EC on part-time work allows Member States, after consultation with their social partners, and for objective reasons, to exclude either wholly or partly from the terms of the directive part-time workers who work on a casual basis. In the same sense, Art. 3 of OIL conv. No. 175 allows Member States to exclude wholly or partly from its scope particular categories of workers if the application of international legislation to them "would raise particular problems of a substantial nature".

It can be observed that these provisions have to be applied in a strict way ${ }^{11}$, because, according to Clause 2 , Par. 2 of European Dir. 97/81, when Member States have opted out it is not a permanent result, because, according to the same provision, "Such exclusions should be reviewed periodically to establish if the objective reasons for making them remain valid".

However, this is an exception that is far from being limited, because neither the EU directive nor the ILO convention prevents part-time workers on a casual basis having to deal with situations where many of their rights are effectively denied. It is not by chance, if the recent and long-awaited proposal for a directive of the European Parliament and of the Council on transparent and predictable working conditions in the European Union $^{12}$, focuses itself on a revision of the EU written statement Directive 91/533 suggesting a set of universal rights that should be valid for all workers, such as: (i) a maximum probation duration period of six months; (ii) making void the employment contract clause which prohibit workers from taking up employment with other employers outside the work schedule established with that employer ("exclusivity clauses"); (iii) predetermined working hours and days schedule for more predictable employment; and (iv) the possibility to request "a form of employment with more predictable and secure working conditions" for atypical workers with at least six months of seniority with the same employer.

It is a topic of great interest also for the ILO, close to a hundred years of history, which is has devoted its General Survey for the annual International Conference to working time, as the other side of the coin to the right to equal pay, to ensure decent work conditions ${ }^{13}$.

Actually, comparative research shows the need for plain provisions, whose respect can be directly requested by workers or can also be ensured by simplified forms of access to justice.

\section{Germany}

The most important form of part time on a casual basis is the German Geringfügige Beschäftigung, internationally known as "mini job" (or "minor" employment, according to ECJ). This kind of employment has been regulated since the 1960s and in 1999 a reform passed to reduce the number of mini-jobbers (more than

\footnotetext{
11 According to ECJ (Jud. 1 March 2012, C-393/10, O'Brien, EU:C:2012:110) also the equal treatment principle of cl. 4 can allow exceptions on "objective grounds" which means that the concept "requires the unequal treatment at issue to respond to a genuine need, be appropriate for achieving the objective pursued and be necessary for that purpose (see, by way of analogy with Clause 5.1(a) of the Framework Agreement on fixed-term work, Del Cerro Alonso, paragraphs 57 and 58)".

${ }_{12}$ Brussels, 21.12.2017 COM(2017) 797 final 2017/0355 (COD).

13 "Ensuring Decent Working Time for the Future", International Labour Conference 107th Session, 2018ILC107(2018)-III(B).
} 
one million at that time). Actually, according to the Hartz Commission's original proposals, "mini jobs" were originally meant to be limited to domestic services. They were intended to legalize the illicit work of the unemployed in this segment.

During the political debate that preceded the reform, many things changed. It was decided to raise the de minimis limit for all sectors from $€ 325$ to $€ 400$, with a substantial exemption from social security contributions and income tax. The limit of less than 15 hours per week was abolished, and another special form of atypical employment (midi-jobs) for with reduced social contributions for employees has been introduced. The intention behind the deregulation was to create a springboard into regular employment. As a matter of fact, the Hartz II reform has raised the numbers of mini-jobbers from 1.7 million (in 2003) to 7.3 million (in 2015).

This increase is due primarily to a sharp rise in the number of mini-jobs taken as second jobs (up almost 1.6 million) as an alternative to do extra-work for the employees on their own work place.

Mini-jobs are particularly common in the cleaning services, hospitality industry, health, and social activities. Over $60 \%$ of mini-jobbers are women, with pensioners and school and university students making up the next biggest group.

Because employers have to pay a flat-rate charge of approximately $30 \%$ on top of the $€ 450$, mini-jobs are technically more expensive per hour than socially insured part-time employment, for which the employers' contributions are around $20 \%$. In fact, the same labour legislation applies to mini-jobs, regarding dismissal protection, paid holiday, sick pay, and maternity leave. In fact, research demonstrates that the average salary is quite a bit lower than the other part time workers, not to say of full time employees.

Although it is universally recognized that the 2003 Reform has promoted work by boosting the low-wage sector, questions have been raised about the side effects such as in-work poverty, lock-in into low quality jobs, and substitution of regular employment with marginal jobs. However, in 2015, the introduction of the minimum wage (now of $€ 8.84 / \mathrm{h}$ ) has re-established an upper limit on weekly working time of around 12 hours (= 51 hours per week), making it easier for the workers to obtain correct payment for sickness and for annual and public holidays.

It is important to stress that in 2003, a "single point of contact" (Minijob-Zentrale) was established for all matters belonging to mini jobs. This agency is competent for all this type of this work in Germany and has 1,650 employees, serving around 2.2 million employers.

\section{France}

Unlike in Germany, where mini-jobs concern all sectors, France has invested in a strategy of integration between welfare policies and the creation of regular employment in the care and assistance to people sectors, through tools aimed at moving from undeclared to regular employment. These devices, made up of tax relief and smart systems of payment, like "vouchers", have paved the way for a social services market in which both formal, profit and non-profit organizations, and individual lenders, hired directly by families, can freely operate and compete.

This is a success story, since up until the first half of the 2000s, the French personal services sector was oriented towards informality and undeclared work, also in the face of the fact that $80 \%$ of the employment relationships directly involved the client and the single worker with cash payment.

With an integrated strategy of reforms able to act jointly on tax and social security contributions, in a few years, the conditions have been set for strong growth in regular employment (with benefits also for the State in 
terms of tax revenue and contributions).

These policies have helped to bring out many of the social services at home from the informal market, helping to develop regular employment in services to people. They also represented an instrument of job placement for those most marginalized on the labor market, unemployed or long-term unemployed, taken care of by means of assistance to combat poverty.

The user of CESU receives a tax-benefit from the State, in the shape of a credit up to $50 \%$ of the cost, which includes salary and social contributions, up to an annual ceiling of $€ 6.000$. Also, the approved bodies (for-profit and not-for profit) providing care and household services receive implicit State support through the partial or full exemption of social contributions and a reduced VAT rate.

There are two types of vouchers: the "CESU declarative" and the "pre-financed CESU (prepaid by a third party)". The first is used by individuals to declare an employee working at home for householding or childcare activities: In this case, the voucher is a payment method and also proof of employment. The second type of voucher is prefunded either by a company for its employees or by local authorities or a social agency for recipients of a benefit. It is issued in the name of the beneficiary and has a predefined amount which can be integrated with additional payments by the users if it does not cover the total amount of the agreed salary.

According to official data, in France, in 2013, 1.29 million workers were employed in the personal and householder services sector ( 958,700 employed by individuals and 435,000 by approved bodies, some workers being hired by several employers, they might be counted twice) and 324,900 were childminders.

The majority of workers who received vouchers for payments are female (94\%), a much higher percentage than in the French labour market as a whole (47\%). There is not an exact correspondence between the voucher and the hourly value of the activity provided: The average hourly wage in the sector corresponded to a net wage, which is often above the minimum wage.

However, only a few workers are not satisfied with their number of hours or with the working time arrangements with single users (an average worker works 22 hours per week).

\section{The Netherlands}

It is well known that the Netherlands is the country with the highest rate of part-time workers, often on a voluntary basis. Not surprisingly, this characteristic seems to have determined particular attention from scholars and jurisprudence in relation to zero-hours contracts and to work on-call.

The part-time contracts are regulated by the civil code and by statutory laws. The number of working hours can be fixed or flexible: In the latter case, the worker is employed "on-call". On-call contracts may stipulate both a minimum and a maximum number of hours a week (min-max contract) or leave this element entirely open (zero-hours contract).

On-call contracts have experimented, according to case law, another differentiation, depending on the fact that employer promises or not a certain amount of hours of work: If he/she does not promise this, there is no proper employment contract but only a preliminary agreement (voorovereenkomst) which regulates the conditions, in case, the parties decide to enter into an employment contract (a fixed-term contract). The second form is an employment contract with a future work obligation (arbeidsovereenkomst met uitgestelde prestatieplicht) which can be both open-ended as well as fixed-term.

It is clear that both legislation on fixed term contracts and on part time employment must be applied in regard to every kind of on-call contract, so that if a worker is employed more than 24 months, he/she will have 
the right to convert his/her contract into an open ended one, following the provisions of Dutch law.

In the same sense, the law states that neither the employer, nor the collective agreements may treat on call employees in a different way, unless objective reasons justify discrimination (for instance different treatment is allowed for pay supplements in case of extra-hours).

Workers employed under contracts which imply future work (FWO) have a right to control their own private life: The relationship between employee and employer is an obligation governed by the principle of good employment practices. Consequently, a "good employer" does not force employees to organize their private life around possible calls, as in the so-called "strangulation contracts" (wurgcontract). The Working Hours Act (Arbeidstijdenwet/WHA) also protects on-call employees by giving them the right to be called at least four days in advance, unless he/she agrees on a shorter period. In any cases, the employer has to take into account the personal situation of employees.

Recently the Court of Justice of The Hague upheld the right to pay during the period of availability in 2017 for taxi drivers, referring to the case law of ECJ (Simap), unless the availability period has taken place at the residential address of the employee.

Finally, the Flexible Work Act (Wet flexibel werken/FWA) gives employees in companies with at least 10 employees the right to adjust working hours and time, or in other words the number of hours and when those hours have to be worked. Every year, the worker can ask for an adjustment of his/her working time and the employer has to take the employee's application into consideration, and has the duty to discuss this with the employee if the request is not agreed to.

\section{Italy}

Since 1992, the Italian Constitutional Court, on the basis of the constitutional right to fair pay, has recognized that a part-time contract must be drawn up in writing and contain a precise indication of the hourly placement of the work activity which means an employee's right to reference days and hours within which work can take place (Ferrante, 2008). It is a very strong and rigid constraint, which does not provide for an explicit individual right of the parties to obtain a modification of agreements previously made, but which can allow the worker to accumulate more than one part time relationship or to dedicate himself to care activities.

The "Biagi" law of 2003 had also provided for, but as a hypothesis not directly attributable to subordinate employment, either a casual or "accessory" job, and also a work on-call contract. The first was paid for by vouchers with a fixed hourly rate and only for "people at risk of social exclusion or in any case not yet having entered the labor market, or about to leave", and exclusively in the context of typified activities (small domestic work of an extraordinary nature, gardening work, and so on). The second, very similar to the Dutch on-call contract, was left to the discipline of collective bargaining, only providing by law that in case of an obligation on the worker to answer to an employer, his/her availability should be remunerated.

Due to the substantial failure of both provisions in counteracting the shadow economy, a subsequent liberalization Act of 2012 has made all restrictions for "casual" work disappear, except for the limits of annual income, thus determining an unexpected growth in the number of workers (even though almost $90 \%$ was a second income), leading shortly thereafter to the major Italian trade union promoting an abrogative referendum, which in fact led in Spring 2017 to a restrictive governmental reform.

The new provision defines different thresholds for the admissibility of recourse to casual work $(€ 5,000.00$ for each lender in a year and an amount equal to half for each employment relationship), but above all provides 
for the right to social security and risk accident insurance: In both cases, the rules appear substantially similar to the previous ones, even if the number of workers employed on this basis has greatly reduced.

In conclusion, the real news compared to the past seem to consist in the restriction to recourse to occasional work, where it is forbidden to replace a previous employment relationship with the new contractual form as well as in the ban on companies with more than five permanent employees or in the agricultural, construction, or contracting sectors stipulating contracts of casual employment.

Due to the uncertainty about its nature (subordinated or sui generis work), it is not clear if part time law can regulate also workers on a casual basis and, consequently, if the principle of equality of treatment must be applied to all casual work (instead equal pay is provided for on-call workers by Art. 17 of d. lgs. 81/2015).

\section{Australia}

Australia has also experienced a strongly growth of casual work from the early 1980s to the mid-1990s as far as the labour market has been de-regulated and became more exposed to international competition. In absence of a detailed legal provision, casual workers are defined as employees without access to leave entitlements.

For this reason, in force of plant level agreements, casual workers are paid a loading on top of their hourly wage rate (usually set at $25 \%$ ) to provide financial compensation for the lack of annual leave, sick pay, and carer's leave.

This feature makes causal work particularly attractive for workers such as students and parents with caring responsibilities who choose this form of work voluntarily, seeking higher remuneration for the small number of hours they are available for work. Other casual workers, instead, may prefer more certainty about their weekly hours of work and more predictable earnings than their current circumstances provide.

There has been some discussion and concern, on the side of employees' organizations, about the risk of a worker remaining trapped in casual employment: It is evident that for some casual employment is a relatively temporary state that provides income in the short term before transitioning to more stable ongoing or permanent employment; for others, casual employment can be a more persistent state.

It is not only a question of job insecurity, but also a practical concern for workers about the possibility to pay regularly weekly rent and other housing costs and may limit their capacity to secure a mortgage for a house. Obviously, financial institutions are accustomed to avoiding risks when lending and requiring evidence from casual workers they have a serious chance of getting reliable stable employment in the foreseeable future.

\section{China}

China presents all the characteristics of a labor market that, after a long season of centralized State control, is slowly moving to a quasi-market economy, where non-standard employment is temporary, seasonal, casual, hourly-paid, up to the point that, in the scholars' terminology, there is no practical difference between "non-standard" and "informal" employment. There are no national statistics to accurately capture the size of shadow economy. Basically, it has to be said that it is a governmental measure to relieve the pressure of rising urban unemployment in the late 1990s and early 2000s to counteract the needs coming from the massive downsizing in the State sector, the rapid expansion of the private economy, and the migration of surplus rural labour en mass to urban areas. 
Despite the lack of official data, it is estimated anyway that over $60 \%$ of the workforce was engaged in "informal employment" by the mid-2000s. Given these premises, it should not come as a surprise that the workers complain about social exploitation, large widespread in-work poverty, poor social security, and workplace welfare provisions. These consequences are particularly severe for those in non-standard employment, who belong to some categories, such as women, foreign, and rural migrant workers.

\section{Conclusion}

Extremely atypical forms of work appear to give an answer to the challenges of the market labour of the urban economies of the 21 st century. The goal of ensuring work for the majority of the population requires legal systems to regulate these forms through special provisions, where the mere application of the principle of equal treatment may seem not to guarantee the effective protection of rights for these workers. This is primarily due to the measure of the remuneration paid which often prevents the worker from fully participating in the labor market and which always appears as an insurmountable obstacle for his/her professional development.

It is not by chance that the recently proclaimed European Social Pillar provides, in two neighboring articles, both the principle of secure and adaptable employment ${ }^{14}$ and the right to a fair wages ${ }^{15}$ : It means that labour has to ensure freedom from want for the worker and his/her family, in a way to prevent in-work poverty.

On the level of social rights, to avoid the risk of splitting normal workplaces into minimal ones (Eichenhofer, 2017, p. 204), the principle of equal treatment must be overcome by recognizing special attention which must be paid to these forms of work, both in terms of protection for maternity, against unemployment, against accidents at work, and in access to social benefits.

However, the contributory scheme must be differentiated, also by means of reduced rates or voluntary contributions (as in Germany), but in such a way as to allow the accumulation of these periods with general seniority, to avoid too fragmented a career. From another point of view, some help in simplification of procedures has to be publically offered to companies (and above all to individual employers) to avoid difficulties in recruitment and to shift people away from preferring to make use of the black economy.

Regulation concerning the minimum wage is essential to allow a more satisfactory recourse to these atypical forms, regardless of the type of contract that actually comes into being, as demonstrated by the German and French experience. It is a question of reacting to the scarce and almost impossible presence of the trade unions on this group of workers, providing for a minimum inter-professional pay level which can respect the autonomy of social partners ${ }^{16}$ without overlapping with the role played by collective bargaining for workers with a higher level of professionalism.

In national systems that still know erga omnes effects of the collective agreement, this measure may appear excessive, but if effective action to combat illegal work has to be ensured, the best solution appears to be recognition of certain individual rights that can be directly implemented by the workers in their day to day relationship with their counterparts. Obviously, the use of centralized payment systems for wages (as in

\footnotetext{
${ }^{14}$ See Art. 5.a. "Regardless of the type and duration of the employment relationship, workers have the right to fair and equal treatment regarding working conditions, access to social protection and training. The transition towards open-ended forms of employment shall be fostered".

${ }^{15}$ See Art. 6.a. Workers have the right to fair wages that provide for a decent standard of living. $b$. Adequate minimum wages shall be ensured, in a way that provide for the satisfaction of the needs of the worker and his/her family in the light of national economic and social conditions, whilst safeguarding access to employment and incentives to seek work. In-work poverty shall be prevented".

${ }^{16}$ See European Social Pillar, n. 6.c.
} 
Germany, France, and Australia) can ensure a very strong barrier to the temptation of a slide into a shadow economy.

The possibility to intervene at international level in the minimum wage is undoubtedly reflected in the ILO's competences and also the recent European Pillar invites the EU institutions to focus themselves on this aspect, in spite of Art. 153.5 TFEU that denies specific compliance on the point.

One wonders if the minimum hourly wage should be differentiated from that otherwise generally recognized, as happens in certain cases, where an additional fee becomes payable, e.g., the absence of a right to leave (like in Australia). This is a difficult question because it is clear that flexibility, in all urban and national contexts, is always (but in a different way) a precarious mode of work which risks altering the balance between wages and personal commitment.

In this sense, the predictability of the timetable is important in order to guarantee the right to a fair wage. In some cases, there are measures of a financial nature, so that the service cannot be interrupted more than once a day (in NL) or the right, however, to three hours of work for each call (in F). In other cases (as in NL), the legal system has been concerned with making the individual working hours schedule highly predictable (in I unilateral modification by the employer is even forbidden for part timers).

The final question regards the role that collective bargaining could play. Experience shows a structural difficulty in organizing those who live their experience as a springboard towards stable work and are therefore not willing to spend their energies on organizing a transitory phase of their life. In any cases, the attitude of individuals towards the variability of their working schedule (and the increase in working hours) is different, since some workers are available to offer more work while others (especially the caregivers) are bound to the rhythms that their family or personal activity impose on them.

The difficulty of identifying an interest common to all, shared by every single worker, must push towards legislative measures, such as provision of a minimum wage, measures aimed at guaranteeing the predictability of the timetable (firstly a right to a reasonable advance notice before a new work assignment), and measures to encourage the transformation of precarious work into permanent work.

Finally, workers' unions are also called upon to play a role in ensuring the effectiveness of the law, also by joining the mechanisms provided by the individual laws (like the Labour inspectorate or ombudsman ${ }^{17}$ ).

\section{References}

Adams, Z., \& Deakin, S. (2014). Re-regulating zero hours contracts. Institute for Employment Rights; UK: Liverpool.

Adams, A., Freedland, M., \& Prassl, J. (2015). The "zero-hours contract": Regulating casual work, or legitimating precarity? Oxford Legal Studies Research Paper No. 00/2015.

Alessi, C. (2017). Il principio di non discriminazione nei rapporti di lavoro atipici. In O. Bonardi, Eguaglianza e divieti di discriminazione nell'era del diritto del lavoro derogabile (pp. 99-130). Roma: Ediesse.

Burri, S., Heeger-Hertter, S., \& Rossetti, S. (2018). On-call work in the Netherlands: Trends, impact, and policy solutions. Geneva: ILO (Conditions of Work and Employment Series No. 103).

\footnotetext{
${ }^{17}$ For Australia, see the website of the Fair Work Ombudsman (at https://www.fairwork.gov.au/), for Europe, see Directive 2009/52/EC of 18 June 2009 providing for "minimum standards on sanctions and measures against employers of illegally staying third-country nationals", which at Art. 6.2.b provides that Member States shall enact mechanisms to ensure that illegally employed third-country nationals [...] may call on the competent authority of the Member State to start procedures to recover outstanding remuneration without the need for them to introduce a claim in that case", the same article provides also that "Illegally employed third-country nationals shall be systematically and objectively informed about their rights under this paragraph and under Article 13 before the enforcement of any return".
} 
Caliendo, M., Fedorets, A., Preuss, M., Schröder, C., \& Wittbrodt, L. (2017). The short-run employment effects of the German minimum wage reform. Bonn: IZA DP No. 11190.

Campbell, I. (2018). On-call and related forms of casual work in New Zealand and Australia. Geneva: ILO (Conditions of Work and Employment Series No. 102).

Ciarini, A. (2016). Servizi alle persone e creazione di nuova occupazione. L'esperienza del CESU in Francia e le possibili riforme per l'Italia. Rapporto Fondazione EYU, Dipartimento di Scienze Sociali ed Economiche—Sapienza Università di Roma

Cooke, F. L., \& Brown, R. (2015). The regulation of non-standard forms of employment in China, Japan and the Republic of Korea. Geneva: ILO (Conditions of Work and Employment Series No. 64).

De Stefano, V. (2016). The rise of the "just-in-time workforce": On-demand work, crowdwork and labour protection in the "gig-economy". Geneva: ILO (Conditions of Work and Employment Series No. 71).

EichenHofer, E. (2017). Precarious work-New implications for social security. In K. Ahlberg and N. Bruun (Eds.), The new foundations of labour law (pp. 197-214). F. a/M., N.Y.: Peter Lang.

Eurofound. (2015). New forms of employment. Publications Office of the European Union, Luxembourg: Eurofound.

Fagan, C., Norman, H., Smith, M., \& González Menéndez, M. C. (2013). In search of good quality part-time employment. Geneva: ILO (Conditions of Work and Employment Series No. 43).

Ferrante, V. (2008). Il tempo di lavoro fra persona e produttività. Torino: Giappichelli.

Galassi, G. (2016). The German mini-jobs reform. Intended and unintended consequances. European University Institute.

Giubboni, S. (2011). La protezione dei lavoratori non standard nel diritto dell'UE. Note introduttive. Rivista giuridica del lavoro, 1, 265-282 (nonché in AA.VV., Studi in onore di Tiziano Treu, Napoli, Jovene, 2011, Vol. III, 1449-1462).

Henly, J. R., \& Lambert, S. (2014). Unpredictable work timing in retail jobs: Implications for employee work-life outcomes. Industrial and Labor Relations Review, 67(3), 986-1016.

Messenger, J. C., \& Wallot, P. (2015). The diversity of "marginal” part-time employment. Geneva: ILO, Policy Brief No. 7.

Schmid, G., \& Wagner, J. (2017). Managing social risks of non-standard employment in Europe. Geneva: ILO (Conditions of Work and Employment Series No. 91).

Thörnquist, A. (2015). False self-employment and other precarious forms of employment in the "grey area" of the labour market. Journal of Comparative Labour Law and Industrial Relations, 31(4), 411-430.

Vallée, G. (2016). Employees' obligation to be available to employers: A (new) pathway to precariousness or a source of flexibility? Journal of Comparative Labour Law and Industrial Relations, 32(3), 275-279.

Watson, I. (2013). Bridges or traps? Casualisation and labour market transitions in Australia. Journal of Industrial Relations, 55(1), 6-37. 